\title{
EUROPEANNESS AND LATE MODERNITY REVISITING THE CONCEPT OF COSMOPOLITAN EUROPE
}

\section{Zoltan GRUNHUT, PhD}

Centre for Economic and Regional Studies, Hungary

grunhut@rkk.hu

\begin{abstract}
The current paper revisits the concept of cosmopolitan Europe developed by Ulrich Beck and Edgar Grande 15 years ago. The objective of this review is to shed light on the increasing actuality of the authors' argument in our social-political constellation suggests that Europe is in desperate need of progressive reinvention. The paper addresses the concept of cosmopolitan Europe in the social theoretical framework of Late Modernity. This lens helps to better understand the future scenarios ahead of the European Union as well as the interlinked options for individual and institutional responses could be taken adequately in this era of global-local changes.
\end{abstract}

Keywords: Europe, Cosmopolitanism, Europeanness, Late Modernity.

\section{Introduction}

Among the prescriptive theories of Europe, like the federalist and confederalist (Burgess, 2007; Saurugger, 2018), and the post-nationalist (Habermas, 1998) concepts, as well as the normative power Europe ideas (Manners, 2008; Whitman, 2011), and the deconstructivist or poststructuralist (anti-colonialist, feminist and non-Eurocentric) interpretations (Kronsell, 2015; Gill, 2000), the conceptualizations of cosmopolitan Europe are specific ones due to certain aspects (cf.: Grunhut, fc.). At first, theorizing cosmopolitan Europe is not about an institutional vision of how to de- and rebuild the European Union (EU) along distinct strategies and actions plans in order to make it more integrated. The key is not to scholarly imagine something great structures for the European citizens, but to encourage them to do this task for themselves. So, cosmopolitan Europe is about the interlinked individual and institutional reflexivity and criticality to construct better ideas of Europe, and according to these perceptions, to create better European structures, as well 
as to provide an empowering institutional environment for European citizens (i.e. to support various forms of ideational agencies, to initiate participation, deliberative discursiveness and inclusion, to advance options for direct governance and civil society intervention, etc.) in order to enable civil actorness (Grunhut, 2019). Cosmopolitan Europe is not about the 'arrival' to somewhere envisioned, since there is no final destination to reach at. It is rather about the 'journey' to continuously strive for something better. It is the state both of individually and institutionally being axiologically yet-to-be (Grunhut, 2020a). A 'work-in-progress' that is normatively not predefined as the individual constitutors and also the principal fundaments of building and rebuilding Europe could pretty much change by time and due to the social attempts to proceed.

So, secondly, cosmopolitan Europe is a specific concept because it is related to a social theory understands the next phase of late modernization as a movement reflexively and critically breaking down the matrix of all sorts of references known from the first (or classic) modernity be these meanings social grand-narratives (rationality, epistemological nationalism, etc.), cultural patterns (norms, codes, taboos, customs, conventions, etc.), social statuses and roles (gender, men's and women's statuses in a society, meaning of family, loveship, marriage, friendship, etc.), hierarchies (class, strata, social position, etc.), established Truths (scientific, religious, or ideological axioms) or formalized structural domains (such as laws, procedures and regularizations) (Beck et al. 1994). According to this theoretical perspective, Europe was already a late modern political project long before it has been started to realize this character of its own self. Actually, the mission to be accomplished is to accept this cosmopolitan shift of Europe, which is the only adequately reflected institutional response to the irreversible global tendencies of Late Modernity.

Among the explicit and implicit concepts of cosmopolitan Europe there are many important theorems proposed by authors with background of sociology (Delanty, 2005; Rumford, 2007; 2008), social theory (Habermas, 2003; 2009; 2013), critical theory and philosophy (Balibar, 2003; Žižek \& Horvat, 2014), or even psychoanalysis (Kristeva, 1998; 2000). None of these theorists is an established scholar from the field of European Studies. And this is not a coincidence if we consider what they are claiming for. Namely that Europe is not a project should be envisioned in a top-down elitist sense, i.e. by decision-makers and stakeholders with the helpful contributions of experts (Grunhut, 2020b). Instead, Europe - they stress - should be built by the citizens' 
Europeanness from bellow. Thus, not the project itself needs to be normatively principled, but the fully democratized and decentralized collective actorness to construct, which is an emancipatory competency of all European agents. Ulrich Beck and Edgar Grande (2007a) remarkably developed this argument in their book entitled 'Cosmopolitan Europe.' Although their concept was mostly addressed by criticism, still it should be considered as one of the most progressive theories about the future of Europe. Not because it is precise, super-consistent and well-elaborated without any misleading predication - criticizers pointed out these flaws rightly (Martell, 2008). On the contrary, Beck and Grande's book is great exactly because it does not strive for strict accuracy and rigid coherency. It purposefully deals with the aspects of how to construct a better Europe instead of showing what to build as a better Europe. So, this approach already invites to actively take part in the ideational, discursive and gesture-based process of citizens' collaboration for Europe - and, at the same time, this is the main message at the heart of the book, the most crucial aim to be achieved, i.e. to empower people that 'we' need to take this into our hands. Accordingly, Beck and Grande do not try to describe cosmopolitan Europe as a future entity. They rather inquire the conditions lead to cosmopolitanization, to this side effect of European integration opens doors for a real cosmopolitan shift. And this latter opportunity is not just the right reflection on the European constellation, but actually the only progressive response to the emerging age of Late Modernity. Thus, Beck and Grande interpret the case of Europe (where we are) in the context of modernization, and by this, they turn their argument into the case for Europe (how we should move ahead). The path is not determined as late modern tendencies in the world are not so enormously intense yet. But we are already in the midst of changes, so the desirable shift, the cosmopolitan one, is on the horizon.

Beck and Grande identify Europeanness as a specific form of cosmopolitanism that does not claim universality for itself, since universalism is fixed and exclusively referenced too. Europeanness is rather a cosmopolitan contingency makes people forget the logic of 'either/or' due to the subjective acceptance of 'both/and.' It is the recognition of others' otherness - no assimilation, no differentiation, but acknowledgment. This is the constitutive process of becoming without othering, the state of being without excluded otherness, the recognition that we are both 'self' and 'other' in our subjectivity. This cosmopolitan Europeanness is a self-transcendent orientation towards the future. A shift from the consummated 'me' and 'us' self-portrayed by fixed 
references from a socially detached and passive position to the contingent 'I' and 'we' continuously self-constituted in a reflexive and critical way by active attachment to others.

Beck and Grande’s argument is 15 years old now. But it has more to say today than ever. And as time passes its actuality will increase. Simply because we are approaching an age where late modern tendencies will be more common, so Europe, which is a late modern entity from its foundation, finally has to be reinvented in a late modern sense. The current paper revisits the concept of cosmopolitan Europe with the aim to remind to this.

\section{Three scenarios of the future of Europe}

Beck and Grande claim that there are three scenarios ahead of Europe. As they say: "The decay scenario assumes that the EU is collapsing under its internal and external contradictions. On this scenario, the EU would not succeed in integrating the new Eastern European member countries economically, in advancing the 'positive,' market-correcting integration of the Community and in reforming and democratizing the European institutions. The result would be that the neoliberal market logic would hollow out the national welfare states and that the political forces which advocate a renationalization of politics would gain new adherents in both the 'old' and the 'new' member states." (Beck \& Grande, 2007a: 414-415) Today, at the end of 2021, this 'decay scenario' is a real threat. The EU is after the Brexit; in Eastern Europe - especially in Hungary, Poland, the Czech Republic and Slovenia - nationalistic governments are accusing 'Brussels' that it is under the influence of 'globalist powers' try to undermine the national, ethnic and cultural homogeneity, the economic stability, as well as the domestic political and social institutions of these societies by supporting (Islam) immigration, LGBTQ+ groups and antitraditionalist NGOs (feminist, pro-abortion, radical green, etc. organizations), as well as 'multinational capitalists' (like the American Jewish philanthropic billionaire George Soros); while in much of the Western European countries emerging EU-skeptic populist political movements are challenging the 'integration-must-stand' narrative. The Hungarian Prime Minister, Viktor Orbán, who is the main propagator of the Europe of Nations idea and who is building coalitions among EU-pessimist parties around Europe, proposed his 7-points plan about the future

of Europe in the summer of 2021 (Text of Orban's speech, 2021). He said: (1) a European 
superstate is undesirable - even in a confederalist sense; (2) the 'ever closer Union' clause should be erased from all EU treaties; (3) the main reason for Europe-wide collaborations is economic prosperity - this should drive all EU policies; (4) the member states' constitutional sovereignty and national identity should not be challenged by supranational institutions; (5) the European Commission has to be reinvented as an executive but non-political actor under the prime influence of the European Council; (6) the national parliaments have to gain greater roles in EU legislative procedures - EU Parliament members should be delegates from the national chambers; and one plus geopolitical request (7) Serbia has to get full membership as soon as possible. There is no need to add remarks to Prime Minister Orbán’s plan - his Europe of Nations idea is basically to unbuild the European integration.

According to Beck and Grande "[T]he stagnation scenario assumes that the EU will succeed in integrating the Eastern European countries into the Community economically and in maintaining a (more or less) functioning internal market. However, the greater heterogeneity in the ranks of the member states will make it impossible to agree on market-correcting policies at the European level. Any further deepening of integration, as well as any extension of the competences of the Community [...] would be blocked by the member states on account of their divergent interests.” (Beck \& Grande, 2007a: 416) Actually, this is our reality for some time respective to the EU integration. Since the Eastern Enlargement of 2004 and 2007, ${ }^{1}$ first the financial crisis and its ramifications, then the refugee crisis has blocked further steps towards a closer unification, while today the corona pandemic is hampering the supranational cooperation. Although Germany and France - the biggest economies and most powerful political actors of the Community - are unbreakable supporters of the policy to strengthen EU institutions and democratize EU politics, however the veto capacity belongs to each member states is preventing these attempts. Today, it is a more urgent task to preserve the integration than to progress with it. Now the EU is frozen in the condition of a neoliberal free trade zone lacking any farther-reaching political claims and with dubious democratic legitimacy. And to get out from this constellation, it is extremely hard because EU policies, politics and polities are assessed by the various actors, both

\footnotetext{
${ }^{1}$ The accession treaty between the EU and Croatia was signed on the 9th December 2011. Since that no accession has been granted to any associated country.
} 
at supranational and national level, through the misleading lens of 'either/or,' i.e. it is either 'more Europe' or 'more nation-states,' - we cannot have both.

So, the scenario of the cosmopolitan shift is based on the assumption that the EU has arrived at a turning point at which its basic status needs to be reassessed, and the only viable option for progressive renewal, which can break both the decay scenario's nationalistic vicious circle and the stagnation scenario's functional paralysis, is cosmopolitanization grounded in the citizens' active Europeanness. Beck and Grande (2007a) emphasize that this shift has to be built on four pillars: (1) strengthening European civil society based on universally shared constitutional norms; (2) the transition to a new post-national model of democracy that, instead of incapacitating the European citizens, accords them an active role in the European decision-making process; (3) introducing a new cosmopolitan approach to integration that is no longer geared to 'harmonizing' rules and overcoming (national) differences but to acknowledging them; (4) establishing Europe as the driving force of a global cosmopolitanism. So, what are these pillars in different terms? (1) Europeanness acknowledges otherness at individual level; (2) Europeanness facilitates civil society actorness; (3) Europeanness recognizes otherness at institutional level; and (4) Europeanness opens towards global togetherness. Beck and Grande argues that these are not expectations ('musts') of the European political project, but opportunities proposed by the much broader social and structural changes of Late Modernity. So the aforementioned pillars could be framed only through this modernization perspective.

\section{Europeanness and otherness at individual level}

There is no clear caesura between Classic and Late Modernity. Modernization is a continuous, non-linear historical process with often changing progressive and regressive stages. However, tendencies show that after the Second World War and especially since the fall of the bipolar world order in 1990-91 when the Soviet bloc collapsed, Globalization has emerged as an unstoppable process (Beck, 1999). And this perception is due to the experience that in our lifeworld (i.e. in our objectified, natural, and social surroundings) a rapid diffusion of 'flows' is progressing (Giddens, 1999). On the one hand, we are witnessing flows of people (tourists, investors, students, guest workers, migrants, refugees, etc.), products and services, innovative techniques and 'best 
practices,' automatized and robotized solutions, digitalized information and Big Data, business and financial interventions, as well as cultural and intellectual streams (in the various fields of art, science, fashion, architecture, lifestyle, etc.). On the other hand, global flows of different threats like ecological and health crises, terrorism, radicalism, state-collapses, financial crises, cyber and international crimes, energy-dependencies, as well as fake news and data corruptions are also observable (Beck, 1992). And this globally interlinked and accelerated lifeworld of 'flows' seriously undermines our local structures, so the realm of formal (regularizing and socially hierarchizing) and informal (culturally reproductive) institutions we are living with as particular and traditional frameworks (Rosa, 2013). Globalization facilitates similar tendencies everywhere. These processes persistently trigger local structures and agents to react. While institutional and subjective reactions may differ to some extent, from a global perspective, these dissimilarities have moderate significance. Therefore, an institutional abstraction proceeds in the late modern context (Giddens, 1990).

This should be seen as an interrelated mechanism of causes and impacts. Globalized dynamics of 'flows' penetrate the local lifeworld and its structural and cultural domains; the induced institutional responses at the local level are fundamentally similar everywhere; these responses are combining into a globally relevant institutional abstraction (universalized institutional unification). At the same time, due to the shaken local lifeworld (the various patterns once framed social interactions are becoming invalid) and because of the uncertainties triggered by these institutional changes, people start to revise their reference-based ideational substances and praxes; they try to rely more on their reflexive competencies and critical agencies to de- and reconstruct individually satisfying understandings and practices for themselves; this explosion of individualization (not egoist individualism but subjective production of the self) facilitates further risks to the social order; so, the continuous de- and rebuilding of local structures and cultures accelerates even more as agents strive for autonomous subjectivity (universalized individualization). Accordingly, the main trend of Late Modernity is the interrelation among the processes of Globalization, institutional abstractions, production of risks and individualization (Grunhut, 2019).

As it was already said in the introduction, the structural tendencies of Late Modernity generate a shift to the individual subjects' way of thinking and doing things. Their ontological 
knowledge (routinized set of epistemic rationale frames ideas and drives praxes) is moving from the 'either/or' to the 'both/and' logic (Beck \& Grande, 2007a). This is the dynamic trend of individualization. The classic modern 'either/or' imposes on the agents an ontological knowledge based on dualities. Through this lens everything is reducible to oppositional binaries, and it is up to the subjects to gather enough information in order to rationally identify the more favorable alternative for them. Although this form of rationality seems to allow individually justified ideas and praxes to compete, however, from a more comprehensive perspective, all of these framings and practices are underpinned by one distinguished generative mechanism - preventing the agents to be able to constitute their unique subjectivity (Grunhut, 2020a). The classic modern 'either/or' logic tolerates the pluralism of ideas and praxes because already at an ontological level it tries to paralyze the subjects' act of (self-)identification. ${ }^{2}$ Due to the 'either/or' logic the attempt to 'identify with' is always shadowed by the negativity of 'differentiate from' (Brons, 2015). So, the agents constitute themselves not inside-out (for something) but outside-in (compare to or against something). They cannot identify any object, natural entity, or human being, just as they cannot address themselves, without a parallel act of differentiation (negative judgment). There is no confirmation without negation. The attraction of something implies the estrangement of others. This is how agents are giving rationalized meanings in the age of Classic Modernity. The act of becoming entails othering, the narrative-performative presentation of being (self-constitution) necessitates that something has to be othered (Grunhut, 2019).

In contrast, the late modern 'both/and' logic encourages subjects to turn away from the useless and invalid references. It questions all binaries and dualities. Late Modernity instead motivates agents to embrace the otherness of others (Beck, 2006). There are no objective and truthful 'codebooks' of patterns or semantics to apply for the act of judging others and their ways of thinking and doing things. Individualization is not only a structurally facilitated social expectation the self needs to cope with. It immanently contains also a precondition to recognize others' similar attempts. The subject could be subjective only in relation to others' acknowledged subjectivity. So, the late modern individualization is a process of endless becoming not against the Other but in mutual embracement with it. This stance of (self-)identification stirs subjects to leave

\footnotetext{
${ }^{2}$ In this paper the term '(self-)identification' is used for the individual act to subjectively understand the world-out-there with all its events, artificial and natural objects, links, social relations, etc. In this sense, understandings of the world-out-there are also framings about the self who propose these ideas. Therefore, identification has two sides - how the subject understands something, it is immanently the subject itself.
} 
behind the ideational and praxes-related routine of differentiation. It is the end of becoming by othering, i.e. to contrast the self and its being to the Other and its otherness. This is not an ethical shift but an ontological revision of one's epistemic prism (cf. Honneth, 1995). Every self is an Other for others. This constellation is eternally given irrespective to any context. However, in the classic modern era, due to the 'either/or' logic, agents could comfort themselves by the perception that 'me' as part of the collective 'us' (in the name of sameness) is protected from the Other and its dangerous otherness by keeping a proper distance. In the late modern era, agents have to change their stance from 'me' to 'I' because there are no references would tell them in compare to whom and according to what aspects they are the same with similar ones (i.e. they could feel 'me' among 'us'). The 'I' is the reflexive and critical self who is ready to revisit the grand-narratives and cultural patterns of its lifeworld; who realizes that there are no 'me' and 'us', only 'we', i.e. similar people with dissimilar perspectives.

So, in this individual constellation Europeanness means that citizens of the EU reflexively and critically de- and reconstruct a contingent subjectivity for themselves (Grunhut, fc). Since guiding references, like particular social patterns and traditional cultural semantics, continuously become void, therefore subjects start to rely more on their fluid and multilayered unique selfhood. The late modern 'both/and' logic encourages them to establish combining local, regional, national and European attachments, intersectional political and non-political civil affiliations, as well as blending artistic and lifestyle affections, without any need for differentiation from others' other kinds of bonds. The more permissive subjects are with their own selves in this process of endless becoming, the more tolerant they are with others' otherness. It is because they repeatedly need to encounter with their own inner-otherness. So, in simple terms, Europeanness could be framed as an embracement of otherness which is both inside and outside of the self.

\section{Europeanness, civil society actorness, and otherness at institutional level}

As it was said, Late Modernity challenges the social and individual self-portrait of unequivocalness once was unshakable in the classic modern era. The emerging new self-portrait of ambiguity triggers subjects to use their actorness. If agents are not consummated, if they cannot be completed in their self-constitution as there are no valid references would assure them to feel 
and experience being fulfilled and accomplished, then subjects have to live a life of active narrative and performative - engagement (Grunhut 2019). In the multilevel institutional complexity of the EU this engagement means to interact not only with sameness but also with otherness; it is being involved in both tried and untried situations; it urges for the subjective construction of relatedness to familiar and unfamiliar social problematizations. The EU could facilitate this cosmopolitan shift of Europeanness at individual level and respective to civil society actorness because it is a late modern entity. It already opens door for reflexively and critically multilayered self-constitution and social-political engagement in many ways. However, the EU's institutional capacities would be appropriate to extend these opportunities to a much wider spectrum.

Beck and Grande argues that "civil society is by far the weakest actor in European politics. To date, a European public sphere has developed in at best a rudimentary form; European parties currently exist only as loose federations of national parties, and even the interest groups which have developed in great numbers in Europe count as mainly weak and ineffective." (Beck Grande, 2007a: 290) They claim that while this is contradictory to the late modern tendencies, it perfectly fits into the Westphalian (nation state-based) world-order of the classic modern era tries to keep the European integration on a neoliberal, free market-oriented, neorealist path. Citizens justifiably feel apathy and distrust towards the EU due to its non-transparent, bureaucratized, too complex and unaccountable policies, politics and polities suffer from democratic deficits (cf. Plottka \& Müller, 2020). Yet isolationist and protectionist reactions do not work either because of the late modern impacts. So, first the EU has to be stimulated from bellow by impulses of civil agents' Europeanness as individual subjects already experience in their everyday lives that the 'national container' is too tight and closed to reflect on global issues and changes. However, this social catalyst cannot remain unsupported for long; it requires progressive institutional responses both from national and supranational agencies. Therefore, a new cosmopolitan alliance between civil society, state and supranational actors must supersede the coalition of neoliberal business and political elites and EU technocrats which has been dominant until now in the process of European integration (Beck \& Grande, 2007a). This latter coalition is not necessarily anti-EU, but they are interested in neoliberal objectives, i.e. in the negative integration of breaking down 'walls,' especially those ones hamper the establishment of a full-fledged self-propelling free market 
(liberated from welfare state interventions, protectionism, redistribution mechanisms, etc.). This elitist coalition envisions a prospering, post-national, efficiently functional technocratic superstate. And these efforts vitalize neonational (i.e. nationalistic, populist, isolationist and disintegrative) responses from the member states. It is because both of these approaches are paralyzed with the classic modern logic of 'either/or.'

The cosmopolitan shift urges for a political reconceptualization of the notions of sovereignty and autonomy. The ability to contribute to the solution of global problems should be the new focus of these notions. And the adjective 'cosmopolitan' designates the extension of both supranational and national capacities for action - internally and externally as well. Why and how? It is because the aforementioned 'flows' of Late Modernity are globally/locally interrelated as well as dynamically changing and evolving (Beck, 1999). Thus, these issues need to be addressed in a glocalized sense, i.e. in a diversely adequate institutional way at all - local, regional, national, supranational and global - level. Cosmopolitan policies, politics and polities of the EU based on Europeanness and legitimized by civil society actorness is the only alternative could sustainably integrate these glocalized - autonomous and sovereign, but also multilaterally reciprocal reflections into something reflexively and critically progressive agency of societies - at least on a European scale. So, the decisive problem to be addressed in the case of sovereignty and autonomy is not gaining or renunciation, like it would be a zero-sum game between the EU and its member states. It is rather the transformation of social-political perceptions of effective capacities for action (Beck, 2006). The nation state-based international actorness has serious limits against the challenges of our time and in the face of late modern tendencies. In light of this, of course, the EU would be similarly wrong to strive for a superstate status. It needs to integrate diversity not harmonized uniformity.

Beck and Grande argues that "[T]he form of Europeanization pursued to date not only weakened the parliaments but also simultaneously strengthened the executives, both at the national and at the European level. The executives are the major beneficiaries of the transfer of power within Europe, and they occupy the control center for institutional reforms. Hence, a democratization of the EU along the established path of treaty revision would presuppose something highly improbable, namely, the voluntary self-disempowerment of the various executives.” (Beck - Grande, 2007a: 423) As regards to the democratization of the EU, Beck and 
Grande stress that first it has to be seen clearly what needs to be democratized and the question of how is relevant just after that. In Europe, they continue, there is a fundamental asymmetry of power. Europe is not congruent with the EU or even with the EU and its various state and nonstate partners. There are all sorts of memberships and partnerships inside Europe. Therefore, an asymmetry of rights and competencies is the core feature of Europe. This is a difference in powers, and this difference should be kept. If Europe is not aiming for a superstate status, and it should not, then integration of institutional diversities has to characterize the Community. Yet, differences could be integrated only if a shared cosmopolitan Europeannness holds together these distinct institutional frameworks. Proposed solutions for policies, politics and polities could be vary, both vertically and horizontally, as long as these institutional responses are driven by the 'both/and' logic of Late Modernity. And exactly this is why not the executive but the legislative powers, which aim to include civil society actorness, should be strengthened inside Europe. The executive branch of power is often aiming for an exclusively representative mode of functionality, in which stakeholders could be respected contributors but not responsible decision-makers. In the case of legislative institutions, it is much easier to install communicative-discursive, deliberative, associative, participatory and consociational set-ups and designs, in which elected representatives and civil society actors could and should cooperate based on constitutional norms. In light of this, Beck and Grande are in favor of the extension of (1) civil intervention options (referendums, public forums, civil steering committees, stakeholder advisory boards, etc.); (2) civil inclusion strategies involve both EU and non-EU citizens from Europe; (3) non-majoritarian decision-models acknowledge otherness (such as veto rights, consensual deliberations, etc.); (4) civil control and monitoring. The authors are aware of the criticism that all of these proposed institutional reforms could end up being dysfunctional. They admit that without a shared Europeanness, should be initiated by the late modern context, reflexive and critical institutional progressivity is impossible. Therefore, the cosmopolitan turn of Europe must start from bellow, by the citizens. Yet people cannot be left unheard for long. So, Beck and Grande consider referendums as particularly important European institutions to develop. They argue that referendums must be genuinely European ones and not a series of uncoordinated national referendums. In this way, the danger that referendums will be misused for national purposes, or even for renationalizing politics, can be minimized. The issues to be decided upon in European referendums should not be restricted. It should be possible to hold them on any issue proposed by a qualified number of European citizens 
(referendums should be initiated by the citizens as a general rule, not by supranational institutions). Not only of a minimum number of citizens but also of citizens from a sufficient number of states should participate in European referendums. The results of these referendums should be binding for the supranational institutions (citizens should not appear as mere petitioners). And finally, referendums should not merely be blocking mechanisms. They have to have the potential to initiate political negotiations, decisions. So, Beck and Grande stress that the supranational support for civil society actorness and active political engagement should start by redesigned European referendums.

\section{Europeanness as an initiation for global cosmopolitanism and togetherness}

Beck and Grande admit that "[A]t first sight, applying the concept of cosmopolitanism to Europe seems to represent a vain attempt to join two things that do not belong together, and indeed cannot coexist, namely the idea of 'world citizenship', on the one hand, and the idea of a continentwide, but nevertheless territorially limited political order, on the other.” (Beck and Grande, 2007b: 70) The authors emphasize that the reinvented idea of cosmopolitanism should reject not just this binary lens and its coordinates, but also the false exclusivity attached to both particularism and universalism. A true cosmopolitan - in their interpretation - aims the prosperity and greatness of its own people (in-group members of sameness) just as much as it wishes the same to other people (out-group members of otherness). Cosmopolitanism suggests that "[D]ifferences should neither be arranged hierarchically nor should they be replaced by common norms, values and standards; rather, they should be accepted as such and even have a positive value placed on them. In a cosmopolitan perspective, it is vital to perceive others as different and as the same - something that is ruled out by both hierarchical ordering and universal equality. Whatever is strange should be regarded and evaluated not as a threat, as something that brings disintegration and fragmentation in its train, but as enriching in the first place.” (ibid: 71) So, cosmopolitanism claims that if people reflexively and critically transform their ontological knowledge (i.e. their routinized set of epistemic rationale frames subjective ideas and drives individual praxes), which is urged but not determined by the emerging tendencies of Late Modernity, then it is possible to achieve both the recognition of individual and of collective otherness. So, this is a transformative meta-change leaves untouched the individual, collective and institutional diversities, but de- and 
reconstructs the substantial meanings of these differences. Beck and Grande stress that “...on this reading, the concept of cosmopolitanism is not defined in spatial terms. It is not tied to the 'cosmos' or the 'globe;' it makes no attempt to include 'everything.' The basic principle of cosmopolitanism may be discovered and applied everywhere, at every level, and in every sphere of social and political activity." (ibid: 72) So, there is no 'EU-centrism' or 'Europeanism' (superiority of European civilization), nor any sort of universalism in the idea of cosmopolitan Europe. It is rather a multidimensional transformative cooperation could be launched on the institutional background of the EU. Again, transformative means that the participant entities of the cooperation (from individual actors through various groups, communities and societies, to public and private agencies) are all aware of the condition that they do not engage in a one-time collaboration happens in fixed structural circumstances and attempts to achieve pre-clarified targets. On the contrary, they are part of a “master plan of not having a master plan.” (Beck - Grande, 2007a: 69) In cosmopolitan Europe actors and agencies are reflexively and critically changing by cooperative interactions, and they continuously alter their institutional frameworks in the same progressive way. "The longer the 'shadow of the future,' the greater are the incentives for the actors involved to cooperate and the greater is the probability that the preferences of the actors, and ultimately the actors themselves, will undergo change as a result." (ibid: 150) As it was already discussed above, Late Modernity deprives us from the reference-based pre-conceptions and visions of the future told in social grand-narratives. Nothing is predestined or prewritten - it teaches; only people have the constitutive competencies and capacities to construct themselves and a future for themselves. Europeanness is this actorness to construct a future Europe could go much beyond what we consider 'Europe' today.

In order to assure that this Europeanness would not strive to create something collective identity founded on a 'superior European civilization' and an 'exceptionally unique European modernization,' agents have to keep in mind three cosmopolitan principles: (1) pan-relationalism (everything is related in our lifeworld - subjects, objects, natural entities, everything is linked together); (2) anti-representationalism (nothing represents itself, every meaning is presented, i.e. subjectively constructed); (3) anti-essentialism (since all meanings are outcomes of constructions, therefore nothing has the status of Truth; there are only subjective justifications) (cf. Rorty, 1989). If these principles are recognized and respected among European citizens, then they would not consider themselves as part of a civilization with a special mission for modernization. A perception 
like that, in contradiction with the 'both/and' logic of cosmopolitanism, (a) negates the relatedness with cultural otherness, (b) tries to frame meanings in a normatively hierarchical sense, and (c) essentializes differences. Beck and Grande warns that the "[S]ensitivity to collectively shared difference is being awakened, first, by the decreasing importance of nation-states, second, by the increasing importance of religion as a focus of identity. In contrast with national or ethnic identities which can be combined and merged, religious identities are mutually exclusive. But it is precisely this that is at the root of the new importance attached to the quasi-essentialistic civilizations conceived as ultimately resistant to any historical, political and social change." (Beck - Grande, 2007a: 241) Europeanness does not have anything in common with the idea of a 'superior European civilization' which is "certainly connected with the dialectic between the dismantling of internal borders and the construction of a fortress against the outside." (ibid: 242) The idea of a 'European fortress' against cultural others is inspired and motivated by 'either/or' kinds of rationales. Those who believe in this idea, especially on the political right, they suggest that "civilization, which is no longer defined exclusively or primarily in religious terms but distinguishes between different historical routes to modernity [...] promises to be fruitful for the social analysis of Europe" as well as for the reinvention of the EU (ibid: 243). The cosmopolitan Europeanness rejects these framings based on superior-inferior civilizations due to one simple reason - "today's others are tomorrow's European 'We'." So, it can be said that "[T]he cosmopolitan outlook forces us to view Europe with the eyes of others too and hence to confront and overcome the provincialization of Europe simultaneously." (ibid: 214) Accordingly, it has to be noted that 'European universalism' based on civilizational or modernization superiority is a classic modern provincial interpretation. The late modern Europeanness "begins where notions of the 'one world,' in which everything could have its proper place, at least in principle and in theory, have been forever shattered." (ibid: 224)

\section{Conclusions}

There are many ideologically legitimate, subjectively justified visions about the future of Europe. Of course, there are fundamental contradictions among these ideas. Yet, there is only one distinguished feature which really points to the core dynamic of these framings of Europe. Namely, 
if they are based on the 'either/or' or the 'both/and' logic. Today it is pretty common to discuss the 'finality' of Europe - if it is progressing towards something loose integration respects national sovereignties and autonomies or if it is striving for a federal integration of a superstate. Although these oppositions seem to be the absolute different ends of a European future, yet if we look at them more closely, they are both motivated by the very same 'either/or' logic. The nationalistic, populist, EU-skeptic approach of the 'Europe of Nations' stresses that we are at a turning point where nations are threatened by the 'hegemonic superpower of Brussels' and the 'deep-state masters' behind the EU project. In the meantime, the federalist, integration-oriented, pro-EU platform claims that autocratic leaders and their 'oligarchs' try to destroy Europe in the name of national pride, while, in fact, they just aim to stabilize their corrupt, nepotistic, antidemocratic regimes. So, both sides emphasize, it is either nationalism or Europe.

There is only one voice outside of this dualism - the concept of cosmopolitan Europe, which, on the one hand, accepts the 'both/and' logic of Late Modernity, and on the other hand, strives to put into perspective the European integration as a late modern endeavor. It does not have an idea of 'European finality;' who knows what the people, i.e. the citizens of Europe will build for themselves? The focus should be instead that Europe has to be built by a cosmopolitan reflexive and critical - Europeanness recognizes otherness at individual, collective and institutional level. Not because cosmopolitanism represents something normatively higher value in compare to Europeanism or nationalism, but because it is the only viable reflection on the late modern tendencies and on the global challenges we are living with - in a more and more complicated sense.

\section{Acknowledgement}

Project FK134893 (Perceptions of „Europe and „Europeanness"e among Young Hungarians) has been implemented with the support provided from the National Research, Development and Innovation Fund of Hungary, financed under the FK20 funding scheme.

\section{References}

1. Balibar, E. (2003) We, the People of Europe? Reflections on Transnational Citizenship. Princeton: Princeton University Press.

2. Beck, U. (1992) Risk Society: Towards a New Modernity. London: Sage. 
3. Beck, U. (1998) World Risk Society. Cambridge: Polity Press.

4. Beck, U. (1999) What Is Globalization? Cambridge: Polity Press.

5. Beck, U. (2006) Cosmopolitan Vision. Cambridge: Polity Press.

6. Beck, U. \& Grande, E. (2007a) Cosmopolitan Europe. Cambridge: Polity Press.

7. Beck, U. \& Grande, E. (2007b) Cosmopolitanism. Europe’s Way Out of Crisis. European Journal of Social Theory, 10 (1), pp. 67-85.

8. Beck, U., Giddens, A. \& Lash, S. (1994) Reflexive Modernization. Politics, Tradition and Aesthetics in the Modern Social Order. Cambridge: Polity Press.

9. Brons, L. (2015) Othering, an Analysis. Transcience, 6 (1), pp. 69-90.

10. Burgess, M. (2007) Federalism and Federation. In Cini, M. (ed.) EU Politics. Oxford: Oxford UP, pp. 69-84.

11. Delanty, G. (2005) The Idea of a Cosmopolitan Europe. International Review of Sociology, 15 (3), pp. 405-421.

12. Giddens, A. (1990) The Consequences of Modernity. Cambridge: Polity.

13. Giddens, A. (1999) Runaway World: How Globalization is Reshaping Our Lives. London: Profile.

14. Gill, S. (2000) Theoretical Foundations of a Neo-Gramscian Analysis of European Integration. In Bieling, H-J. \& Steinhilber, J. (eds.) Dimensions of a Critical Theory of European Integration. Marburg: Universität Marburg, pp. 15-32.

15. Grunhut, Z. (2019) Reflexive Europe and the Era of Late Modernity. Acta Baltica Historiae et Philosophiae Scientiarum, 7 (3), pp. 42-57.

16. Grunhut, Z. (2020a) Europe in the Late Modern Social Acceleration. The 'Spokespeople' of European Studies. On-line Journal Modelling the New Europe, 33, pp. 4-24.

17. Grunhut, Z. (2020b) The 'Expertisation’ of European Studies. A Critical Perspective on Discursive Institutionalism. Eastern Journal of European Studies, 11 (1), pp. 252-272.

18. Grunhut, Z. (forthcoming) Building Europe by Europeanness. Revisiting the Concept of Cosmopolitan Europe. Eastern Journal of European Studies

19. Habermas, J. (1998) The Post-national Constellation. Cambridge MA: MIT Press.

20. Habermas, J. (2003) Towards a Cosmopolitan Europe. Journal of Democracy, 14 (4), pp. 86100.

21. Habermas, J. (2009) Europe. The Faltering Project. London: Polity. 
22. Habermas, J. (2012) The Crisis of the European Union. London, Polity.

23. Honneth, A. (1995) The Struggle for Recognition: The Moral Grammar of Social Conflicts. London: Polity.

24. Kristeva, J. (1998) ‘Europhilia, Europhobia’. Constellations, 5 (3): 321-332.

25. Kristeva, J. (2000) Crisis of the European Subject. New York: Other Press.

26. Kronsell, A. (2015) The Power of EU Masculinities: A Feminist Contribution to European Integration Theory. Journal of Common Market Studies, 54 (1), pp. 104-120.

27. Manners, I. (2008) The Normative Power of the European Union in a Globalised World. In Laïdi, Z. (ed.) EU Foreign Policy in a Globalized World: Normative Power and Social Preferences. London: Routledge, pp. 23-37.

28. Martell, L. (2008): Beck’s Cosmopolitan Politics. Contemporary Politics, 14 (2), pp. 129143.

29. Plottka, J. \& Müller, M. (2020) Enhancing the EU's Democratic Legitimacy. Short and LongTerm Avenues to Reinforce Parliamentary and Participative Democracy at the EU Level. Munich: Friedrich Ebert Stiftung.

30. Rorty, R. (1989) Contingency, Irony and Solidarity. Cambridge MA: Cambridge University Press.

31. Rosa, H. (2013) Social Acceleration. A New Theory of Modernity. New York: Columbia University Press.

32. Rumford, C. (2007) Cosmopolitanism and Europe. Liverpool: Liverpool UP.

33. Rumford, C. (2008) Cosmopolitan Spaces: Europe, Globalization, Theory. Abingdon-New York: Routledge.

34. Saurugger, S. (2018) The European Union and Federalism: Possibilities and Limits. In Grin, G., Nicod, F. \& Altermatt, B. (eds.) Forms of Europe. Paris: Economica, pp. 173-200.

35. Whitman, R. G. (ed.) (2011) Normative Power Europe: Empirical and Theoretical Perspectives. Basingstoke: Palgrave Macmillan.

36. Žižek, S. \& Horvat, S. (2014) What Does Europe Want? The Union and Its Discontents. New York: Columbia University Press. Full text of PM Orbán's speech on the future of the European Union. Fidesz.hu. 2021. https://fidesz.hu/int/news/pm-orbans-speech-on-the-fu. 